\title{
METHODICAL APPROACHES FOR CONFESSIONAL REGIONALIZATION OF UKRAINE
}

\author{
Ivan KOSTASCHUK \\ Yurii Fedkovych Chernivtsi National University, Ukraine \\ ivan_kostaschuk@ukr.net
}

\begin{abstract}
The paper presents the review of previously made schemes of sacral (religious, confessional) regionalization of the territory of Ukraine, presented in the works of human geographers. Taking into account these elaborations, their advantages and deficiencies, the author proposes own methodology of confessional regionalization, including its basic principles and criteria. Confessional regions, sub-regions, areas and localities are proposed to be the units of confessional regionalization of the territory of Ukraine. The developed methodology allowed identifying 6 confessional regions in Ukraine, with 2 of them further divided into sub-regions. This approach to regionalization allowed better trace regional patterns of confessional structure, including dominant confessions and their relationships. The necessity of this study is dictated by the need to develop a state strategy for the development of inter-confessional and state relationships, as well as the implementation of the state regional policy in the field of religion in certain regions of Ukraine. The proposed methodology of confessional regionalization can be adopted for other countries or their parts.

Key words: religious regionalization, confessional regionalization, confession, regionalization, principles and criteria of regionalization, religious activity.
\end{abstract}

DOI: https://doi.org/10.17721/2413-7154/2018.79.22-30

UDC: 911.3

Received: December 08, 2017.

Revised: May 18, 2018.

Accepted: May 20, 2018.

\section{МЕТОДИЧНІ ПІДХОДИ ДО ПРОВЕДЕННЯ КОНФЕСІЙНОГО РАЙОНУВАННЯ ТЕРИТОРІї УКРАїНИ}

\author{
Іван КОСТАЩУК
}

Чернівецький національний університет імені Юрія Федьковича, Україна ivan_kostaschuk@ukr.net

Анотація: Релігійне районування території будь-якої держави чи її частини є досить важливим завданням сучасної суспільної географії, так як дозволяє краще простежити спільні конфесійні риси на окремих територіях та розробляти державну стратегію розвитку міжконфесійних та державно-конфесійних відносин та взаємин, а також запобігання виникненню релігійних конфліктів різних видів, підтримці соціального служіння церков різних конфесій, напрямів та течій.

Метою написання даної статті було передбачено аналіз існуючих схем релігійного районування території України, а також удосконалення методики його проведення та застосування на практиці. У даній статті проаналізовано попередньо проведені схеми сакрального (релігійного) районування території України, що представлені в працях суспільних географів; обґрунтовано методику проведення конфесійного районування території України, виділено основні його принципи та критерії.

Методика проведення релігійного районування базувалася на співставленні конфесійної структури та показників релігійної активності населення, а саме індексу релігійної мозаїчності, показників забезпеченості населення і поселень громадами різних конфесій, напрямів та течій.

Нами обґрунтовано поділ території України на конфесійні райони та підрайони. Внаслідок проведення наукових досліджень згідно розробленої методики, нам вдалося виділити в Україні 6 конфесійних районів, а саме: Західноукраїнський (Волинський, Галицький, Подільсько-Буковинський та Закарпатський підрайони), Волино-Подільський, Придніпровсько-Столичний, Центрально-Причорноморсько-Кримський (Кримський підрайон), Східний та Північно-Східний. Саме таке районування дозволяє краще простежити переважаючі конфесії та їх співвідношення з метою врахування особливостей управління на місцевому та державному рівні.

Ключові слова: релігійне районування, конфесійне районування, конфесія, районування, принципи та критерії районування, релігійна активність населення. 


\section{Introduction}

Modern society, being at the informational stage of development, has faced many inter-ethnic and interconfessional conflicts that have exacerbated the problem of confessional peace, both in the world as a whole and in Ukraine in particular. Scientific research of religious and, eminently, confessional space today is inevitable and much in demand by the society. Geographical researches, studying the confessional space and its regionalization, are of particular relevance, as only they allow clear identification and tracing the spatial divisions in the confessional space, understanding the causes of the origin of religious conflicts and making appropriate forecasts, as well as developing ways of their alleviation.

Such studies are especially important for modern Ukraine, where the relationships between two Orthodox confessions, namely the Ukrainian Orthodox Church and the Ukrainian Orthodox Church of the Kyiv Patriarchate, as well as between the Ukrainian Orthodox Church and the Ukrainian Greek Catholic Church, have worsened. In our opinion, confessional regionalization should be carried out in compliance with numerous principles and criteria meeting the methodological requirements of human geography.

Therefore, the research represented in this paper seems to be relevant and promising, as it contributes to the development of the theoretical and methodological base of human geography in general and the geography of religion in particular, which in turn provides a better understanding and generates new approaches to geographical research of confessional and religious spaces.

\section{Theoretical and methodological background}

The following scholars have focused on confessional space and spatial patterns of the religious sphere in Ukraine and its separate oblasts: F. Zastavnyi, O. Liubitseva, K. Mezentsev, I. Rovenchak, M. Dnistryansky, S. Pavlov, L. Shevchuk, A. Kovalchuk (the whole territory of Ukraine), L. Nemets, K. Nemets, L. Kluchko (Kharkiv oblast), O. Kuchabsky (Lviv oblast), V. Patiychuk (Volhyn oblast), Yu. Kogatko (Chernihiv oblast), I. Kostaschuk (Chernivtsi oblast), L. Ataman (Podolian region, including Vinnytsia, Khmelnytsky and Ternopil oblasts), and others. Such scholars as O. Topchiev, O. Shabliy, A. Golikov, Ya. Oliynyk, M. Pistun and others (Ukraine), H. Park, L. Kong and others (Great Britain), P. Zukerman, V. Lowell, R. Horace, J. Esposito, S. Hitchcock and many others (USA), K. Matsui (Japan), S. Gorokhov, T. Khristov and others (Russia) and many other scholars from around the world devoted their scientific works to the theoretical and methodological substantiation of the geography of religion as an important human geography branch.

Almost every of these scholars studied the issue of religious-geographical regionalization from the standpoint of human geography. Their works substantiate the criteria, principles and grounds of making regionalization based on religion patterns. However, the existing methods of religious confessional regionalization practically do not take into account the religious activity of the population as a factor in the development and formation of the

(C) Ivan Kostaschuk confessional space, being an integral part of the religious and sacred spaces.

\section{Study goals and objectives}

The purpose of this paper is to analyze and generalize the existing criteria, principles, approaches and methods of confessional regionalization with the subsequent the elaboration of the own regionalization methodology and its approbation carrying out the confessional regionalization of Ukraine. In accordance with the goal we set the following tasks: to analyze the previous methods and schemes of religious regionalization of Ukraine; to offer one's own methodology of confessional regionalization generalizing the previous experience, including various criteria, principles, approaches and methods; to perform confessional regionalization of Ukraine; to determine the further significance and prospects of geographical research of religious and confessional spaces.

\section{Review of existing schemes of religious regionalization of Ukraine}

It should be noted that all existing schemes of religious regionalization were developed by the authors using various approaches and methods, as well as using different criteria for the identification of religious or confessional regions. Therefore, to improve the methodology of confessional regionalization, we have analyzed already existing schemes.

The first religious regionalization of the territory of Ukraine was conducted in 1994 by O. Shabliy, who distinguished 4 religious regions: Western (Volhyn, Zhytomyr, Rivne, Vinnytsia, Khmelnytsky, Ternopil, Ivano-Frankivsk, Lviv, Chernivtsi and Transcarpathian oblasts); Central (Kyiv, Chernihiv, Sumy, Cherkasy, Kirovohrad and Poltava oblasts); Eastern (Donetsk, Luhansk, Kharkiv and Dnipropetrovsk oblasts); Southern (Crimea, Odessa, Zaporizhia, Mykolaiv and Kherson oblasts) [18]. It is worth noting that due to the confessional heterogeneity, the Western region was further divided into several more zones, namely: Transcarpathian, Western Volhynian, Bukovinian, Galician and PodolianVolhynian [18]. L. Shevchuk follows this scheme of regionalization in his scientific works [19]. The main criterion that underlies such regionalization is the religious activity of the population, which is characterized by the number of existing religious communities, as well as their religious affiliation.

In the scientific work "Geography of religions: the main tasks and prospects of development" [13], V. Patiychuk presented a scheme of religious regionalization with five religious regions: Western (Chernivtsi, Volhyn, Transcarpathian, IvanoFrankivsk, Khmelnytsky, Ternopil, Rivne and Lviv oblasts); Northern (Chernihiv, Kyiv, Zhytomyr, Cherkasy, Poltava, Sumy, Kharkiv and Vinnytsia oblasts); Eastern (Kirovohrad, Dnipropetrovsk, Zaporizhia, Donetsk and Luhansk oblasts); Southern (Odessa, Kherson and Mykolaiv oblasts); Crimean (Autonomous Republic of Crimea). The basis of such regionalization was the number of denominations and their relative weight in the religious sphere, as well as factors influencing the process of the religious space formation and their manifestation. 
Religious regionalization, proposed by S. Pavlov, K. Mezentsev and O. Lyubitseva [12], reflects primarily the confessional structure of the population, the number of religious communities of different denominations, and existing trends. This scheme provided for seven religious regions: Volhynian (Rivne, north of Ternopil and Volhyn oblast); Halychyna (Ivano-Frankivsk, Lviv, and the southern part of the Ternopil oblast); Transcarpathian (Transcarpathian oblast); Central (Kyiv, Poltava, Chernihiv, Zhytomyr, Sumy, Kirovohrad and Cherkasy oblasts); Podolian-Bukovynian (Chernivtsi, Khmelnytsky and Vinnytsia oblasts); Southeastern (Donetsk, Luhansk, Zaporizhia, Kharkiv and Dnipropetrovsk oblasts) and Southern (Kherson, Odessa, Mykolaiv oblasts and the Autonomous Republic of Crimea). It should be noted that this scheme took into account not only the boundaries of administrative oblasts, but also historical regions, which we consider to be certainly a correct and scientifically grounded approach.

The religious regionalization of Ukraine, done by A. Kovalchuk [5], deserves a special attention. The main criteria that underlie this regionalization scheme are confessional structure, ethno-cultural aspects, as well as historical peculiarities of the formation of the territory of each administrative oblast. With this approach, the author identified 9 religious regions: Galician (Lviv, IvanoFrankivsk and almost all Ternopil oblast, except for the northern part); West Volhynian (Volhyn, Rivne and north of the Ternopil oblast); Transcarpathian (Transcarpathian oblast); Bukovynian (Chernivtsi oblast); VolhynianPodolian (Vinnytsia, Zhytomyr and Khmelnytsky oblasts); Central-North (Sumy, Chernihiv, Kyiv, Poltava and Cherkasy oblasts); Central-Southern (Odessa, Kirovohrad, Mykolaiv and Kherson oblasts); Crimean (Crimea) and Eastern (Dnipropetrovsk, Zaporizhia, Donetsk, Luhansk and Kharkiv oblasts) [5].

In addition to the schemes of religious regionalization of Ukraine, we analyzed also the relevant schemes at the regional level, identifying main approaches and principles used. Particular attention deserves the religious regionalization of Kharkiv (L. Kliuchko), Chernihiv (Yu. Kogatko) oblasts and Podolia (L. Ataman).

Proposed methodology for confessional regionalization

The confessional regionalization we understand as a scientifically substantiated division of a certain territory into separate parts (regions, sub-regions, areas, etc.), which are distinguished by the peculiarities of the confessional structure formed under the influence of various factors, primarily the historical and geographical features, as well as religious activity of the population.

It should be noted that in our study we differentiate between the religious (sacral) and confessional regionalization that arise from the human-geographical essence of the religious space and its proposed structure. Religious space we consider as a part of the sacred space, which in turn we divide into confessional space, atheists, agnostics and akirchs. The confessional space reflects the distribution of individual denominations and is divided into subspaces (Orthodox, Catholic, Protestant, Jewish, Muslim, pagan, etc.). Atheists are people who believe that God, like any other kind of high powers, do not exist. Agnostics are people who do not recognize the existence of God and other high powers, and argue that religion is created only to form moral and ethical norms in society. Akirchs are people who believe in God, but do not attribute themselves to any denomination, direction or course, believing that they are not needed by society.

Doing the confessional regionalization, which covers only the confessional figures and does not take into account the number of atheists, agnostics and akirchs, we propose to determine the rating place of a certain territory among others using the following indicators: the index of religious mosaics, the number of religious communities per population for each denomination separately; the number of clerics, presbyters and missionaries per population for each denomination separately; the number of clerics, presbyters and missionaries for separate settlements that is also calculated for each denomination separately.

To study the religious mosaic, we have interpreted the Ekkel's index of ethnic mosaicand and got the following mathematical model:

$$
R j=1-\sum_{i=1}^{n}(\pi r)^{2},
$$

where $\mathrm{Rj}$ stands for index of ethnic mosaic, and $\Pi r$ is a share of religious communities of a certain denomination in confessional structure of the region. The higher values of $\mathrm{Rj}$ corresponds to more variegated confessional structure of the region.

We suggest the four following indices to determine the availability of religious services in certain regions:

1) Availability of religious communities for population, which can be calculated using the formula:

$$
\mathbf{P}_{\mathrm{r}}=\mathbf{R} / \mathbf{N},
$$

where $P_{r}$ is the index of availability of religious communities for population, $\mathrm{R}$ stands for the number of religious communities in the region, and $\mathrm{N}$ signifies the population of the given region, in thousands of people.

2) Availability of religious communities for settlements:

$$
\mathbf{R}_{\mathbf{n}}=\mathbf{R} / \mathbf{P}
$$

where $R_{n}$ is the index of availability of religious communities in settlements, $\mathrm{R}$ stands for the number of religious communities in the region, while $\mathrm{P}$ signifies the number of settlements in the region.

3) Availability of clergy for settlements:

$$
\mathbf{P s}=\mathbf{S} / \mathbf{N},
$$

where Ps is the index of availability of clergy in settlements, $\mathrm{S}$ is the number of clergy of the region, and $\mathrm{N}$ stands for the population of the region.

4) Availability of clergy for religious communities:

$$
\mathbf{R s}=\mathbf{S} / \mathbf{R},
$$

where Rs stands for the index of availability of clergy of a certain denomination for religious communities, $\mathrm{S}$ is the number of clergy of the region and $\mathrm{R}$ is the number of religious communities of the region. 
Thus, having conducted the appropriate calculations for the denominations submitted in the report of the Ministry of Culture of Ukraine and the reports of the relevant regional state administrations (Form 1), we will receive 221 indicators, which certainly allows us to accurately determine the similarity of administrative regions by the confessional structure and religious activity of the population, which manifests itself in the number of religious communities and clergy in reference to the population.

To increase the role of the relative weight of the main confession and other denominations, we propose to make 5 rating ranks: the first one is the index of religious mosaics, the second is the average indicator of the density of religious communities per 1000 people, the third is the average indicator of the availability of religious communities for settlements, the fourth is the average indicator of the availability of clergy for settlements and the fifth is the average indicator of the availability of clergy for religious communities. The second, third, fourth and fifth rows reflect the rating of the region as the average value calculated for 55 denominations. Thus, theindicatorofthereligiousmosaic index is not lost among the 221 indicators, but is one of the five important criteria.

After making appropriate calculations and creating the rating of Ukrainian regions by the indicators of availability of religious communities for the population and settlements, as well as by the indicator of the religious mosaic index, we received an average indicator reflecting the religious activity and the confessional structure of the region.

In our opinion, the territorial structure of confessional space represents a quantitative and qualitative combination of all existing denominations and trends, in particular relevant religious communities. We propose to use the following elements of the territorial structure:

Confessional region covers an area having specific features of the manifestation and the course of interconfessional relations, as well as historical, geographical and religious prerequisites for religious commonalities.

Confessional sub-region includes a part of the confessional region that slightly differs in some aspects of confessional structure.

Confessional province is a part of the confessional region with clear expressed peculiarities of confessional structure, which itself may include some local territorial units - confessional localities.

Proposed scheme of confessional regionalization of Ukraine

As a result of the corresponding calculations, we found that the high indices of religious mosaic in Kherson, Kirovohrad and Zaporizhia oblasts (Table 1) is achieved due to the rather high proportion of certain Protestant denominations, in particular Christians of the Evangelical Faith - Pentecostals (CCEP) and Evangelical Christians - Baptists (ECB), and in Kherson oblast there is also a significant proportion of the Ukrainian Autocephalous Church (UAOC) communities. For the city of Kyiv, as an important administrative, spiritual and cultural center of Ukraine, the share of all denominations is significant - Orthodoxy (41.1\%), Catholicism (4.3\%), Protestantism (38.1\%), the other $(16.5 \%)$. The high religious mosaic in the Chernivtsi oblast is achieved due to a high proportion of different confessions, including not only the dominating Ukrainian Orthodox Church (UOC), but also various Protestant denominations $(25.0 \%)$, the Ukrainian Orthodox Church of the Kyiv Patriarchate (UOC-KP, 14.2\%), the Ukrainian Greek Catholic Church (UGCC) and the Roman Catholic Church (RCC, 5.0\%).

Low indices of religious mosaic are typical for Galicia (Lviv, Ivano-Frankivsk and Ternopil oblasts), where the confessions of the UGCC, the UOC-KP, and the UAOC remain dominant, which significantly suppresses the influence of other denominations, as well as for Novgorod-Sivershchyna and Slobozhanschyna (Chernihiv, Sumy and Luhansk oblasts), where the UOC remains the dominant confession, and the population is not religiously active, as evidenced by the numerous temples that are closed today.

Such regions as Volhynia (Volhyn and Rivne oblasts), Podolia (Khmelnytsky and Vinnytsia oblasts), Central Dnipro (Dnipropetrovsk oblast), where Orthodoxy is dominant and traditional, are at the stage of transition to a high religious diversity of denominations and communities; the same refers to Transcarpathian oblast, where Orthodoxy and Greek-Catholicism are widespread, and the Crimea, where the communities of Orthodox and Muslims are almost equal.

The conducted calculations allowed us to reveal the following spatial patterns:

1) Regions of the Western Ukraine are the most active in religious life, which, in our opinion, can be explained by the fact that these areas were least influenced by the atheistic power of the Soviet Union, and they managed to preserve the spiritual culture and, accordingly, quickly restored the religious communities of different denominations. In addition, in the late 1980s, representatives of the UGCC and the UAOC returned there from exile, which significantly affected the number of religious communities;

2) Kirovohrad, Zaporizhia and Kherson oblasts are leaders by the indicator of religious mosaics, but they are significantly inferior by the other two indicators. This is due to the fact that in these regions have small total number of religious communities, but of different denominations, among which there is a significant proportion of Protestant trends. This indicates that in these regions, the Ukrainian Orthodoxy may lose the prevailing influence in religious life in some time;

3) Eastern regions of Ukraine, where the UOC is the dominant confession, remain the least religiously active, including visiting temples or other prayer houses.

Based on the rating results, we managed to hold confessional regionalization of the territory of Ukraine and identify the following confessional regions and subregions (Figure 1):

Western Ukrainian confessional region, which includes Chernivtsi, Ivano-Frankivsk, Lviv, Transcarpathian, Ternopil, Khmelnytsky, Volhyn and Rivne oblasts. It can be divided into four sub-regions: 1) Volhinian sub-region, including Volhyn and Rivne 
Religious mosaic of Ukrainian regions (as for January 1, 2017)

\begin{tabular}{|l|c|c|}
\hline \multicolumn{1}{|c|}{ Administrative territorial units } & Index of Religious Mosaic (IRM) & Rating by IRM \\
\hline UKRAINE & 0.802016 & - \\
\hline Autonomous Republic of Crimea (with Sevastopol) & 0.729246 & 16 \\
\hline Vinnytsia & 0.703249 & 15 \\
\hline Volhyn & 0.72945 & 18 \\
\hline Dnipropetrovsk & 0.71426 & 10 \\
\hline Donetsk & 0.747208 & 12 \\
\hline Zhytomyr & 0.74201 & 14 \\
\hline Transcarpathian & 0.732736 & 24 \\
\hline Zaporizhia & 0.780788 & 7 \\
\hline Ivano-Frankivsk & 0.64807 & 3 \\
\hline Kyiv & 0.753638 & 21 \\
\hline Kirovohrad & 0.784184 & 25 \\
\hline Luhansk & 0.688322 & 6 \\
\hline Lviv & 0.616752 & 8 \\
\hline Mykolaiv & 0.76177 & 11 \\
\hline Odessa & 0.749152 & 17 \\
\hline Poltava & 0.744432 & 23 \\
\hline Rivne & 0.722948 & 22 \\
\hline Sumy & 0.661972 & 9 \\
\hline Ternopil & 0.68009 & 2 \\
\hline Kharkiv & 0.747574 & 20 \\
\hline Kherson & 0.784554 & 13 \\
\hline Khmelnytsky & 0.692264 & 5 \\
\hline Cherkasy & 0.735506 & 26 \\
\hline Chernivtsi & 0.77824 & 0.575278 \\
\hline Chernihiv & 0.842272 & \\
\hline City of Kyiv & & \\
\hline & & 2 \\
\hline
\end{tabular}

oblasts, as well as Kremenets, Shumsk and Lanivtsi districts of Ternopil oblast, where the Orthodoxy of both directions (UOC and UOC-KP) dominates; 2) Galician sub-region, including Lviv, Ternopil (without Kremenets, Shumsk and Lanivtsi districts) and IvanoFrankivsk oblasts with predominance of the UGCC, UAOC, UOC-KP and RCC comunities; 3) PodolianBukovynian sub-region, including Khmelnytsky and Chernivtsi oblasts, where the UOC-MPs dominates in the confessional structure, while the communities of the UOC-KP and Protestant movements are also noticeable; 4) Transcarpathian sub-region, which includes the single respective oblast and is characterized by the significant share of the UOC, RCC and UGCC communities.

Volhynian-Podolian confessional region, which includes Zhytomyr and Vinnytsia oblasts. It is characterized by the domination of Orthodox trends, the UOC and the UOC-KP, with a significant proportion of the RCC and the Protestant trends.

Capital Dnieper confessional region, including Kyiv and Cherkasy oblasts, as well as the city of Kyiv. This region, due to the powerful gravity effect of Kyiv, is characterized by an active religious life, the prevalence of Orthodoxy and the presence of all religious organizations registered in Ukraine, including a significant proportion of new religious trends.

Central, Black Sea and Crimean confessionalgeographical region, which includes Odessa, Kirovohrad, Mykolaiv, Kherson, Zaporizhia and Autonomous Republic of Crimea. The Orthodox faith (UOC) is prevailing, but at the same time there is a considerable proportion of Protestant communities; however, the total number of religious communities is quite low. The Crimean sub-region stands out with a significant proportion of Muslim population.

Eastern confessional region is represented by Dnipropetrovsk, Kharkiv, Donetsk and Luhansk oblasts. It is characterized by low religious activity, the prevalence of Orthodoxy (UOC) with a significant proportion of Protestant communities.

North-Eastern confessional region includes Chernihiv, Sumy and Poltava oblasts, where Orthodoxy is dominant, but the level of religious activity is rather low, as evidenced by the rather small number of registered religious communities.

Thus, by means of the confessional regionalization of the territory of Ukraine, performed in accordance with the elaborated methodology, we managed to 


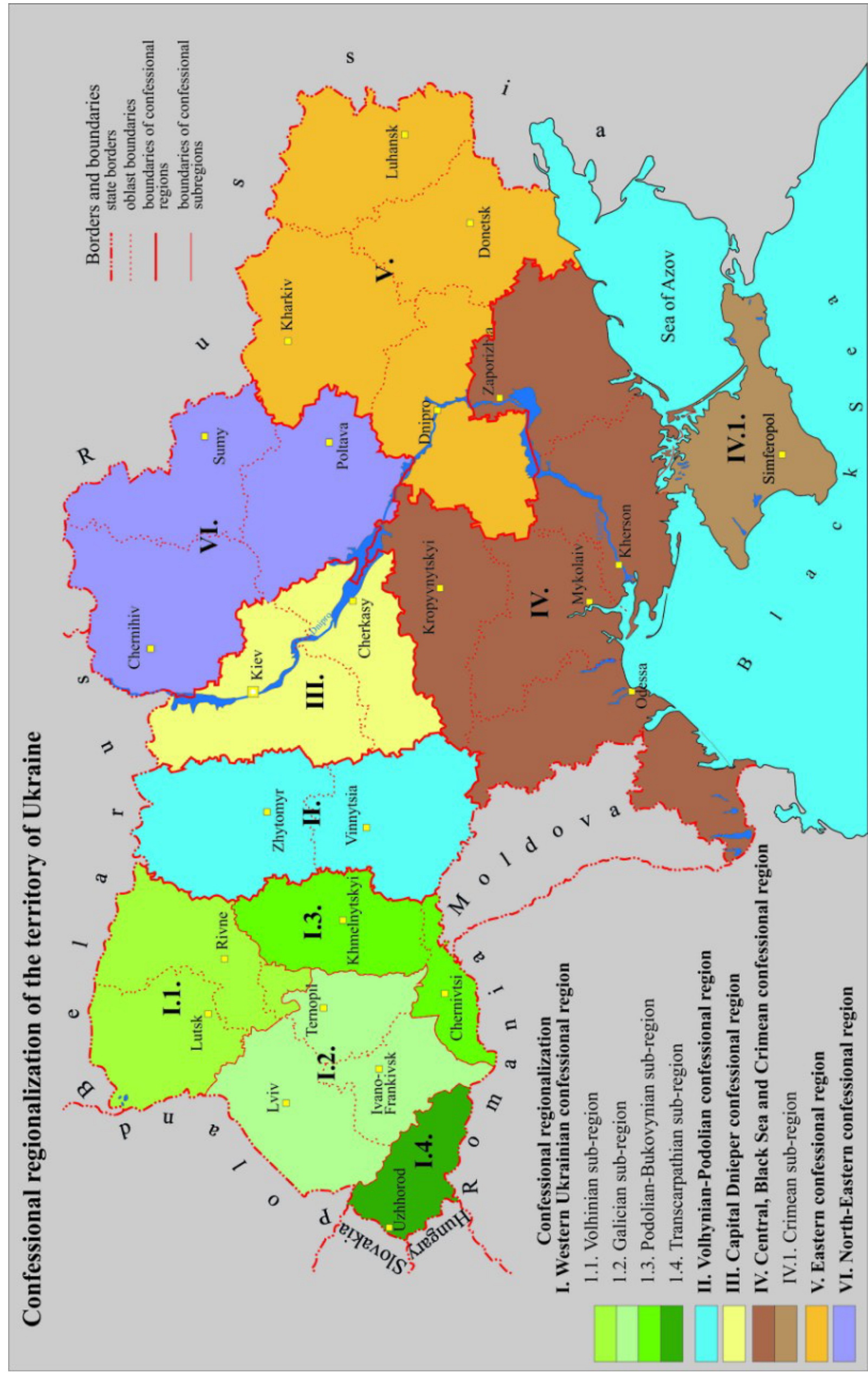

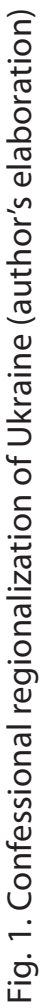


identify 6 regions, two of which have additionally separate sub-regions.

It should be emphasizes that such a scheme of confessional regionalization of Ukraine substantially differs from the previous elaborations. Firstly, it takes into account not only the boundaries of modern administrative territorial units, but also the limits of historical geographical regions. Secondly, this scheme is based not only on the ratio of individual confessions and denominations, but also takes into account a number of indicators of religious activity - the aspect practically not covered in the previous analysis. Our approach to confessional regionalization is based on the following key basic principles of confessional regionalization: confessional mosaicism, religious activity, territorial proximity, as well as specificity of inter-confessional relations manifested by the level of conflict.

\section{Conclusions}

Investigation of the confessional space as an integral part of the religious and sacred spaces is relevant scientific task having both theoretical and practical significance. It solves important issues concerning inter-faith and inter-ethnic, cultural, moral, ethical social relations etc. The confessional regionalization is quite an advisable and sometimes necessary instrument for the development of policy relating to churchstate and inter-confessional relations in separate regions and the state as a whole. Therefore, the results of this research can be used by the relevant departments of regional state administrations, as well as by the Department of Religious Affairs and Nationalities of the Ministry of Culture of Ukraine.

\section{References:}

1. Ataman L. Issledovanie sakral'nogo prostranstva regiona: metodologiâ i principy [Investigation of the sacral space of the region: methodology and principles]. Pskovskij regionologičeskij žurnal [Pskov Journal of Regional Geography], 2015, Vol. 23, pp. 107-117. (In Russian).

2. Golikov A., Oliynyk Ya., Stepanenko A. Vstup do ekonomičnoï ta social'nö̈ geografï [Introduction to economic and social geography]. Kyiv, 1997, 320 p. (In Ukrainian).

3. Gorohov S. Religioznaâ identičnost' kak faktor formirovaniâ konfessional'nyh regionov sovremennogo mira [Religious identity as a factor in the formation of confessional regions of the modern world]. Moscow University Bulletin. Series 5. Geography, 2012, N. 5, pp. 49-55. (In Russian).

4. Kliuchko L. V. Suspil'no-geografǐčnì doslìdžennâ relìgìjnoï sferi [Religious sphere: view of human geography]. Časopis social'no-ekonomičnoï geografï [Human Geography Journal], 2008, Vol. 5 (2), pp. 216-220. (In Ukrainian).

5. Kovalchuk A. Relìgìjno-geografične rajonuvannâ: kriteriii ì pokazniki [Religious-geographical regionalization: criteria and indicators]. Ukrainian Geographical Journal, 2000, Vol. 3, pp. 40-43. (In Ukrainian).

6. Kogatko Yu., Mezentsev K. Metodi doslìdžennâ geografii relìgìj: docìl'nìst' vikoristannâ, sistematizaciâ, potencìal kartografičnogo ta centrografičnogo metodìv [Scientific methods of the geography of religion: the expediency, systematization, potential of cartographic and centrographic methods]. Bulletin of Taras Shevchenko National University of Kyiv. Geography, 2009, Vol. 56, pp. 30-36. (In Ukrainian).

7. Kostaschuk I. Teritorìal'na organìzaciâ relìgìjnoï sferi regìonìv Ukraïni [Territorial organization of the religious sphere of the Ukrainian regions]. Scientific Bulletin of Vernadsky Taurida National University. Series: Geography, 2011, Vol. 24 (63), N. 2, Ch. 3, pp. 137-143. (In Ukrainian).

8. Kuchabskyi O. İntegral'ne relìgìjno-geografǐčne rajonuvannâ L'vìvs'koï oblastì [Integral religious-geographical regionalization of Lviv region]. The scientific issues of Ternopil Volodymyr Hnatiuk National Pedagogical University. Series: Geography, 2000, N. 1, pp. 80-85.

9. Liubitseva O. Relìgìjna situaciâ v Ukraïnì ta îi regìonal'nì osoblivostì [Religious situation in Ukraine and its regional specificities]. Ukrainian Geographical Journal, 2009, Vol. 4, pp. 28-32. (In Ukrainian).

10. Niemets K., Niemets L., Kliuchko L. Prostorovì aspekti analìzu relìgìjnoï sferi (na prikladì Harkìvs'koï oblastì) [Spatial aspects of the analysis of the religious sphere (on the example of the Kharkiv region)]. Ćasopis social'noekonomičnoï geografï [Human Geography Journal], 2009, Vol. 6 (1), pp. 151-158. (In Ukrainian).

11. Oliynyk Ya., Stepanenko A. Vstup do social'noï geografï [Introduction to the social geography]. Kyiv: Znannya, 2000, 204 p. (In Ukrainian).

12. Pavlov S., Mezentsev K., Liubitseva O. Geografiya religij [Geography of religion]. Kyiv: Artek, 1998,504 p. (In Ukrainian).

13. Patijchuk V. O. Teritorìal'na organizaciâ relìijnoï sferi admìnistrativnoï oblastì (na prikladì Volins'koï oblasti) [Territorial organization of the religious sphere of the administrative region (the case of Volhyn region)]. PhD Thesis. Lutsk: Lesya Ukrainka Volhynian State University, 1998, 202 p. (In Ukrainian).

14. Pistun M. Osnovi teorii suspil'noï geografï [Human geography: fundamentals of the theory]. Kyiv: Vyscha shkola, 1994, 156 p. (In Ukrainian).

15. Rovenchak I. Geokul'turnì risi konfesìjno-geografǐčnogo podìlu Zahìdnogo regìonu Ukraïni (na prikladì UGKC) [Geocultural features of confessional-geographical regionalization of the Western region of Ukraine (on the example of the Ukrainian Greek Catholic Church)]. Ekonomiko-, social'no- i ekologogeografični problemi zahidnoukrä̈ns'kogo prikordonnâ: Tematičnij zbirnik naukovih prac' [Economic, social, and ecological geographical problems of the Western Ukrainian borderland: Thematic collection of scientific works]. 
Lviv: Lviv State University, 1997, pp. 69-78. (In Ukrainian).

16. Topchiev O. Suspil'no-geografičnì doslìdžennâ: metodologiâ, metodi, metodiki [Research in human geography: methodology, methods, techniques]. Odesa: Astroprynt, 2005, 632 p. (In Ukrainian).

17. Hristov T. Religioznyj turizm [Religious tourism]. Moscow: Akademiya, 2005, 288 p. (In Russian).

18. Shablij O. Social'no-ekonomična geografiâ Ukraïni [Social and economic geography of Ukraine]. Lviv: Svit, 1994, pp. 423-440.

19. Shevchuk L. Sakral'na geografiâ [Sacral geography]. Lviv: Svit, 1999, 160 p. (In Ukrainian).

20. Ekkel B. Opredelenie indeksa mozaičnosti nacional'nogo sostava respublik, kraev i oblastej SSSR [Determination of the mosaic index of the national composition of the republics, territories and regions of the USSR]. Sovetskaâ ètnografiâ [Soviet Ethnography], 1976, N. 2, pp. 33-42. (In Russian).

21. Hitchcock Susan Tyler, John L. Esposito. Geography of religion: where God lives, where pilgrims walk. National Geographic Society (U.S.), 2010, 416 p.

22. Kong L. Geography and religion: trends and prospects. Progress in Human Geography, 1990, Vol. 14, N. 3, pp. 355-371.

23. Livezey, Lowell W., ed. Public Religion and Urban Transformation: Faith in the City. New York University Press, 2000, $364 \mathrm{p}$.

24. Matsui Keisuke. Geography of Religion in Japan: Religious Space, Landscape, and Behavior. New York: Springer, 2014, 199 p.

25. Park C. C. Sacred Worlds: an Introduction to Geography and Religion. London: Routledge, 1994, 287 p.

26. Zuckerman, Phil. Invitation to the Sociology of Religion. NY, New York: Routledge, 2003, 166 p.

\section{Список використаних джерел:}

1. Атаман Л. В. Исследование сакрального пространства региона: методология и принципы / Л.В. Атаман // Псковский регионологический журнал. - 2015. - № 23. - С. 107-117.

2. Голіков А. П. Вступ до економічної та соціальної географії / А.П. Голіков, Я.Б. Олійник, А.В. Степаненко. - Київ, 1997. - 320 с.

3. Горохов С. А. Религиозная идентичность как фактор формирования конфессиональных регионов современного мира / С. А. Горохов // Вестник Московского университета. Серия 5: География. - 2012. - № 5. - C. 49-55.

4. Ключко Л. В. Суспільно-географічні дослідження релігійної сфери / Л.В. Ключко // Часопис соціальноекономічної географії. - 2008. - Вип. 5(2). - С. 216-220.

5. Ковальчук А. С. Релігійно-географічне районування: критерії і показники / А. С. Ковальчук // Український географічний журнал. - 2000. - № 3. - С. 40-43.

6. Когатько Ю. Л. Методи дослідження географії релігій: доцільність використання, систематизація, потенціал картографічного та центрографічного методів / Ю.Л. Когатько, К.В. Мезенцев // Вісник Київського національного університету імені Тараса Шевченка. Географія. - 2009. - Вип. 56. - С. 30-36.

7. Костащук I. I. Територіальна організація релігійної сфери регіонів України / I.I. Костащук // Ученые записки Таврического национального университета им. В.И. Вернадского. Серия «География». Спец. выпуск. - 2011. - Том 24 (63). - № 2. - Ч. 3. - С. 137-143.

8. Кучабський О. Г. Інтегральне релігійно-географічне районування Львівської області // Наукові записки тернопільського педагогічного університету ім. Володимира Гнатюка. - Серія: Географія. - 2000. - №1. - C.80-85.

9. Любіцева О.О. Релігійна ситуація в Україні та їі регіональні особливості / О.О. Любіцева // Український географічний журнал. - 2009. - Вип. 4. - С. 28-32.

10. Нємець К. А. Просторові аспекти аналізу релігійної сфери (на прикладі Харківської області) / К. А. Нємець, Л. М. Нємець, Л. В. Ключко // Часопис соціально-економічної географії. - 2009. - Вип. 6 (1). - C. $151-158$.

11. Олійник Я. Б. Вступ до соціальної географії: Навч. посібник / Я. Б. Олійник, А. В. Степаненко. - К.: Т-во «Знання», КОО, 2000. - 204 с.

12. Павлов С. В. Географія релігій. Навчальний посібник для студентів географічних і філософських факультетів / С. В. Павлов, К. В. Мезенцев, О. О. Любіцева. - К.: Артек, 1998. - 504 с.

13. Патійчук В. О. Територіальна організація релігійної сфери адміністративної області (на прикладі Волинської області): дис. кандидата географічних наук 11.00.02 / В. О. Патійчук. - Луцьк: Волинський державний університет імені Лесі Українки, 1998. - 202 с.

14. Пістун М. Д. Основи теорії суспільної географії : навчальний посібник для студентів географічних спеціальних вузів / М. Д. Пістун. - К.: Вища школа, 1994. - 156 с.

15. Ровенчак I. І. Геокультурні риси конфесійно-географічного поділу Західного регіону України (на прикладі УГКЦ) // Економіко-, соціально- і еколого-географічні проблеми західноукраїнського прикордоння: Тем. зб. наук. праць. - Л.: ЛДУ, 1997. - С. 69-78.

16. Топчієв О. Г. Суспільно-географічні дослідження: методологія, методи, методики: Навчальний посібник / О.Г. Топчієв. Одеса: Астропринт, 2005. - 632 с. 
17. Христов Т. Т. Религиозный туризм. Учебное пособие. / Т. Т. Христов. - М.: ИЦ «Академия», 2005. -288 c.

18. Шаблій О. І. Соціально-економічна географія України / За ред. О. І. Шаблія. - Л.: Світ, 1994. - 608 с.

19. Шевчук Л. Т. Сакральна географія / Л. Т. Шевчук. - Львів: Світ, 1999. - 160 с.

20. Эккель Б. М. Определение индекса мозаичности национального состава республик, краев и областей СССР / Б. М. Эккель. Советская этнография. - 1976. - №2. - С. 33-42

21. Hitchcock S. T. Geography of religion: where God lives, where pilgrims walk / S. T. Hitchcock, L. John. National Geographic Society (U.S.), 2010. - 416 p.

22. Kong L. Geography and religion: trends and prospects / Kong L. // Progress in Human Geography. - 1990. - Vol. 14. - N. 3. - P. 355-371.

23. Livezey, L. W., ed. Public Religion and Urban Transformation: Faith in the City. - New York University Press, 2000. $-364 \mathrm{p}$.

24. Matsui K. Geography of Religion in Japan: Religious Space, Landscape, and Behavior / K. Matsui. - New York: Springer, 2014. - 364 p.

25. Park C.C. Sacred Worlds: an Introduction to. Geography and Religion / C. C. Park. - London: Routledge, 1994. $-287 \mathrm{p}$.

26. Zuckerman, P. Invitation to the Sociology of Religion / P. Zuckerman. - New York, NY: Routledge. $-2003 .-166 \mathrm{p}$. 